\title{
Federal Enclaves and Local Law: Carving Out a Domestic Violence Exception To Exclusive
}

\section{Legislative Jurisdiction}

\author{
Michael J. Malinowski
}

\section{INTRODUCTION}

Diane Cobb, a member of the United States Armed Forces, resides and works in a federal enclave. ${ }^{1}$ Solely because of this, questions of law arose as to whether a Massachusetts state court could issue a restraining order to protect her and her infant child from an abusive and dangerous civilian husband, ${ }^{2}$ and whether such a state-generated order even would be enforceable in a federal enclave. $^{3}$

The jurisdiction of federal courts does not reach into domestic relations. ${ }^{4}$

1. Cobb. v. Cobb, 406 Mass. 21, 545 N.E.2d 1161 (1989). Federal enclaves are pockets of federallyowned property within states, over which the federal government often holds exclusive legislative jurisdiction. Besides serving as military installations, federal enclaves have been established to serve as national parks, nuclear power plants, post offices, and the nation's capital.

Throughout this Note, "federal enclave" refers to military bases under exclusive federal legislative jurisdiction. Within the United States, there are 871 military installations with $2,774,100$ soldiers and employees. DEPARTMENT OF DEFENSE, LIST OF MIITARY INSTALlatIONS, AUTHORIZED FULL-TIME ASSIGNED PERSONNEL (INCLUDING FY 1987). This figure, however, does not include the family members of these personnel. In fact, $51 \%$ of enlisted service people and $40 \%$ of officers have children under six years of age. Griffith, Research Triangle Institute, Description of Spouses of Officers and Enlisted Personnel in the U.S. Armed Forces: 1985 (1986) (report based on 1985 DoD surveys of officers, enlisted personnel, and military spouses); see also UNITED STATES DEPARTMENT OF DEFENSE, DEFENSE '87 ALMANAC 30, 33 (Sept.-Oct. 1987).

2. "In the six months preceding the filing of the complaint [by Diane Cobb], the defendant pushed [her], kicked her, threw a knife at her and threw a brick through her car windshield while she sat in the car." Brief and Appendix of Plaintiff/Appellee Diane Cobb at 4, Cobb v. Cobb, 406 Mass. 21, 545 N.E.2d 1161 (1989) (No. SJC-5039) [hereinafter Plaintiff Brief].

3. The author selected the case of $C o b b v$. $C o b b$ for discussion, not only because it triggered an amicus brief from the United States Department of Justice on behalf of the Department of the Army, but also because it illustrates the identifiable effect of the enclave problem-_"the recurring question of what relief is available from state courts to residents of military installations within state boundaries who suffer domestic abuse." Brief of Amicus Curiae the Department of the Army in Support of Appellee Diane Cobb at 6, Cobb v. Cobb, 406 Mass. 21, 545 N.E.2d 1161 (No. SJC-5039) [hereinafter Army Brief]. Empirical measurement of the potential effects of this problem-i.e., the extent to which jurisdictionally unsure state courts refuse to issue such orders and the extent to which such orders, once issued, are not enforced by base commanders-is beyond the scope of this Note.

4. See infra note 44 and accompanying text; Hisquierdo v. Hisquierdo, 439 U.S. 572,581 (1979) ("The whole subject of the domestic relations of husband and wife, parent and child, belongs to the laws of the States and not to the laws of the United States.'") (quoting In Re Burrus, 136 U.S. 586, 593-94 (1890)); 
Yet, the extent to which the victims of domestic violence ${ }^{5}$ who reside on federal enclaves can import state law relief onto these islands of federal jurisdiction is not clear.

The exclusive legislation clause, ${ }^{6}$ supremacy clause, ${ }^{7}$ and property clause ${ }^{8}$ empower the federal government and its agents to insure that federal interests are served on government enclaves. What constitutes a "federal interest" is, to a large extent, left to the discretion of military commanders. ${ }^{9}$ Therefore, a commander may shield military personnel from a state regulation or court order that interferes with the performance of assigned duties-for example, a temporary restraining order (TRO) issued by a state court to keep an abusive soldier away from his $^{10}$ enclave residence. ${ }^{11}$

see also Simms v. Simms, 175 U.S. 162 (1899). For a full discussion of the domestic relations exception to federal law in light of federal-state jurisdiction, see Rush, Domestic Relations Law: Federal Jurisdiction and State Sovereignty in Perspective, 60 NOTRE DAME L. REV. 1, 1-2 (1984):

Three theories support the exception by suggesting that federal courts historically lacked power to grant divorces, award alimony, and determine child custody because: (i) diversity jurisdiction originally did not extend to these suits; (ii) the jurisdiction of article III courts was never intended to extend to these matters; and (iii) such issues are reserved to the states through the [T]enth Amendment.

5. "Domestic violence" refers to violence occurring within a household or between members of a household, "violence" meaning:

Unjust or unwarranted exercise of force, usually with the accompaniment of vehemence, outrage or fury. Physical force unlawfully exercised; abuse of force; that force which is employed against common right, against the laws, and against public liberty. The exertion of any physical force so as to injure, damage or abuse.

BLACK'S LAW DICTIONARY 1570 (6th ed. 1990) (citations omitted).

6. U.S. CONST. art. I, $\$ 8$, cl. 17 (Congress shall have the power "[t]o exercise exclusive Legislation in all Cases whatscever ... over all Places purchased by the Consent of the Legislature of the State in which the Same shall be, for the Erection of Forts, Magazines, Arsenals, dock-Yards, and other needful Buildings.").

7. U.S. CoNST. art. VI, cl. 2 ("This Constitution, and the Laws of the United States which shall be made in Pursuance thereof . . . shall be the supreme Law of the Land; and the Judges in every State shall be bound thereby, any Thing in the Constitution or Laws of the State to the Contrary notwithstanding." ). Note that, although the United States cannot unilaterally acquire federal jurisdiction over a state's land without the consent of that state's legislature, and the state legislature may reserve some rights (to serve process, for example), the supremacy clause prohibits a state reservation from being "inconsistent with the free and effective use" of the land for federal purposes. See Fort Leavenworth R.R. v. Lowe, 114 U.S. 525, 539 (1885) (supremacy requires nonapplicability of state laws interfering with ownership and use of real property by federal government); see infra text accompanying notes 17-22 (discussing concept of exclusive legislative jurisdiction more fully). It follows that the effect of supremacy is to grant immunity to distinctly federal activities.

8. U.S. CONST. art. IV, $\S 3, \mathrm{cl} .2$ ("The Congress shall have Power to dispose of and make all needful Rules and Regulations respecting the Territory or other Property belonging to the United States . ..." $)$. See American Fed. of Gov. Employees v. F.L.R.A., 802 F.2d 1159, 1163 (1986) (holding California's right to license drivers not infringed by naval weapons station's suspension of driving privileges on station's property, on grounds that "[t]he federal government may control its property free from regulation by the states unless Congress declares that the property is subject to state regulation").

9. See infra note 43 and accompanying text.

10. Throughout this Note, masculine pronouns are used to refer to abusers, while feminine pronouns are used to refer to their victims. This division most accurately parallels the fact patterns of the majority of reported domestic violence cases.

11. For discussion of the constitutional provisions granting interference immunity to federal interests, see Gaetke, Refuting the "Classic" Property Clause Theory, 63 N.C.L. REv. 617 (1985) (constitutional analysis regarding relevant clauses); see also Altieri, Federal Enclaves: The Impact of Exclusive Legislative 
The issue of enforcement, however, may never arise since state courts, afraid of stepping beyond their jurisdiction, might hesitate to issue such orders. ${ }^{12}$ The ironic result of this apprehension is that, even when the military's interests are aligned with those of the victim, military interests may be frustrated: when the abuser is a civilian outside of the military's jurisdiction (and the victim of domestic violence is a soldier such as Diane Cobb), the military might be impotent to address the situation without a state court order. ${ }^{13}$

Congress should carve a domestic violence exception out of the exclusive legislative jurisdiction of federal enclaves so that all enclave domestic violence victims are assured legal recourse. ${ }^{14}$ In the absence of a congressional response, courts should continue to respond to domestic violence actions through a modified doctrine of noninterference. Presently, this doctrine utilizes a presumption in favor of applying state law in the area of domestic relations, but only to the extent that state law does not conflict with federal law and

Jurisdiction Upon Civil Litigation, 72 MIL. L. REV. 55, 58 (1976) ("Tt clearly appears throughout the early legislative history that this idea of prevention of state interference with governmental activities was the primary concern of the framers in considering the need for exclusive jurisdiction."); Engdahl, Federalism and Energy: State and Federal Power over Federal Property, 18 ARZ. L. REV. 283 (1976) (interpretation of property clause regarding federal land).

12. Diane Cobb was issued a temporary restraining order by the Ayer District Court on December 6 , 1988 , but the trial court issuing the order also reported two questions to the Supreme Judicial Court: (i) Does a Massachusetts trial court lack the power to issue a restraining order for a member of the United States Armed Forces who resides and works on a military enclave, and, (ii) once issued, is such an order legally effective within the confines of a military enclave? See Plaintiff Brief, supra note 2, at 1 . These questions proved important enough to generate a brief of amicus curiae from the Department of the Army. See Army Brief, supra note 3.

On December 12, 1988, Diane's temporary restraining order was extended until June 11, 1989, pending direct appellate review of the preceding questions by the Supreme Judicial Court. The Supreme Judicial Court, after noting that the $C o b b$ case was moot because the temporary restraining order expired on its own terms (oral arguments were heard on September 5, 1989), avoided resolving the doctrinal confusion enmeshing enclave litigants (see infra text accompanying notes $23-43$ ) by simply acknowledging a trend toward applying the doctrine of noninterference: "Opinions of the United States Supreme Court in more recent years have shown that the Constitution of the United States does not bar extension of the benefits and burdens of all State laws to inhabitants of land ceded to the Federal government." Cobb v. Cobb, 406 Mass. 21, 24, 545 N.E.2d 1161, 1163 (1989). The Court, applying the doctrine of noninterference, found that: (i) the restraining order was effective against the defendant as to his conduct off ceded land; and, (ii) "[i]n the absence of any indication that such an order interfered with the Federal function," the order was also effective against the defendant's conduct when on ceded land. Id. at 1164 (emphasis added).

13. See infra note 62; see also Army Brief, supra note 3, at 2: "I]f enclave residents in Mrs. Cobb's situation are denied access to state courts for relief, they may be left with no recourse at all since the jurisdiction of military tribunals does not extend to spouses, like Mr. Cobb, who reside on federal enclaves, but are not members of the armed forces." (citation omitted).

14. See Note, Federal Enclaves-Through the Looking Glass-Darkly, 15 SYRACUSE L. REV. 754 (1964) (commentary supporting failed 1960's Congressional effort to codify state and agency jurisdiction within federal enclaves). For a general survey of the federal enclave issue, with a focus on procedural questions, see also Altieri, supra note 11. In the instance of "essential" federal functions, federal immunity also applies to activities conducted off enclaves, for example, Army personnel entering private property to retrieve downed aircraft. For a more extreme application, see Johnson v. Maryland, 254 U.S. 51 (1920) (holding state cannot constitutionally require federal employee to secure driver's permit before operating motor vehicle to perform federal duties). 
military regulations, nor interfere with the federal function of the enclave. ${ }^{15}$ This state law presumption is not enough, for as soon as a military commander claims that applying state law grinds against federal interest, the presumption dissolves. To this presumption must be added the recognition that protecting all victims of domestic violence is a substantial federal interest with which other government interests should not interfere.

This Note begins in Part I by establishing the federal purpose behind exclusive legislative jurisdiction, and explaining how the failure of states to condition cession $^{16}$ of their lands to the federal government left courts no clear direction for addressing questions regarding the private rights of enclave residents. The Note then presents three doctrinal approaches taken by courts to resolve the problem of enclave litigation and demonstrates their unpredictability. It also substantiates that there is, in light of this unpredictability, a potential lack of legal recourse for the victims of domestic violence who reside on federal enclaves. Part II presents the factual background of $C o b b$ v. Cobb, a recent illustration of the enclave problem, and uses this case to rethink the legal doctrine. Part III proposes a solution that would provide greater certainty of legal recourse for all victims of domestic violence on federal enclaves, whether they be soldier or civilian, adult or child.

\section{Defining the Problem: The Law's Treatment of Enclave DOMESTIC VIOLENCE}

\section{A. Background: Beyond the Expectation of the Framers}

The notion of distancing certain federal functions from the states in which these federal functions are carried out originated with the inability of Philadelphia's local government to maintain order during the Continental Congress:

In June of 1783 the Continental Congress, meeting in Philadelphia, was subjected to four days of harassment by soldiers [mutineers from the Continental Army] demanding their pay. Although there was no physical violence, the proceedings were disrupted and the Congress was forced to leave the city. The inability of the local government to control the rioting was a matter of serious concern to the legislators. ${ }^{17}$

15. See Howard v. Commissioners of Louisville, 344 U.S. 624 (1953) (often cited for viewing enclave as being within a state and providing arguments for extension to enclave residents of civil rights belonging to state citizens).

16. Cession is "[t]he assignment, transfer, or yielding up of territory by one state or government to another." BLACK's LAW DICTIONARY 228 (6th ed. 1990).

17. Altieri, supra note 11, at 57-58 (citations omitted); see also Fort Leavenworth R.R. v. Lowe, 114 U.S. 525, 539 (1885) (stressing federal government is entitled to "free and effective use" of enclave property for federal purposes). 
The Framers were concerned that their new government be protected from interference, but, during the state ratifying conventions, the power of exclusive legislation over enclave areas was questioned. ${ }^{18}$ Madison's response in The Federalist Papers articulated the lasting principle behind the doctrine of exclusive legislative jurisdiction: the need to protect federal functions in enclave areas from the interference and excessive influence of any state. ${ }^{19}$

Protecting such federal functions is what the Framers intended to do. Never did they intend to go so far as to rip the fabric of state law out of these federal pockets, for it was the "expectation of the Framers that the power of exclusive jurisdiction would not be strictly viewed, and that a residual state jurisdiction could continue within the enclave as to private matters not interfering with federal functions."20

Despite the expectation of the Framers and the fact that jurisdiction given is forever gone, ${ }^{21}$ states did not place conditions on cession to protect private rights. ${ }^{22}$ This left the law unclear and the private rights of enclave residents undefined. Over time, the courts have generated three distinct approaches to enclave-based litigation while fumbling with the private rights of enclave residents.

\section{B. The Three Doctrinal Approaches to Enclave Litigation ${ }^{23}$}

Conflict among various Supreme Court enclave precedents has resulted in three separate approaches to enclave-based litigation: the McGlinn (international

18. Altieri, supra note 11 , at $57-58$ (citations omitted).

19. THE FEDERALIST No. 43, at 273 (J. Madison) (C. Rossiter ed. 1961):

The public money expended on such places, and the public property deposited in them, require that they should be exempt from the authority of the particular State. Nor would it be proper for the places on which the security of the entire Union may depend to be in any degree dependent on a particular member of it.

20. Altieri, supra note 11 , at 60 . One commentator has suggested that "[c]onstruing the clause as conferring a power to legislate exclusively [having the power to trump other legislative bodies with one's legislation] rather than an exclusive power to legislate [holding the sole power to legislate] would make it ample for its apparent purpose, and would comport with the earliest evidence of the drafters' intent." Engdahl, supra note 11 , at 289 . In contrast, for an intent argument that the "real" classic property clause theory calls for an expansive view of federal property clause power, see Gaetke, supra note 11.

21. A state cannot unilaterally recapture jurisdiction ceded to the Federal Government. See United States v. Unzeuta, 281 U.S. 138, 143 (1930) (" $[$ A]fter this jurisdiction had been accepted by the United States, it could not be recaptured by the action of the state alone ...."); Yellowstone Park Transp. Co. v. Gallatin County, 31 F.2d 644, 645 (9th Cir.) ("In other words, after the date of cession, the ceded territory was as much without the jurisdiction of the state making that cession as was any other foreign territory, except in so far as jurisdiction was expressly reserved."), cert. denied, 280 U.S. 555 (1929).

22. The sole exception is Virginia's cession of land for the District of Columbia:

And provided also, That the jurisdiction of the laws of this commonwealth over the persons and property of individuals residing within the limits of the cession aforesaid, shall not cease or determine until Congress, having accepted the said cession, shall, by law, provide for the government thereof, under their jurisdiction, in manner provided by the articles of the Constitution before recited.

Act of Cession from the State of Virginia, D.C. CODE ANN. $\$ 1$ (1981).

23. For a more thorough summary of the litigation history marking the evolution of these doctrines, see Altieri, supra note 11. 
law) rule, ${ }^{24}$ the Paul rule, ${ }^{25}$ and the Howard (noninterference) rule. ${ }^{26}$ The McGlinn rule mandates that: "whenever political jurisdiction and legislative power over any territory are transferred from one ... sovereign to another, the ... laws[,] which are intended for the protection of private rights, continue in force until abrogated or changed by the new government or sovereign."27 According to this doctrine, when jurisdiction is transferred from a state to the federal government to form an enclave, the state law in existence at the time of the transfer becomes federal law. State statutory and common law changes made subsequent to the transfer, however, have no force within the enclave unless authorized by specific congressional legislation. ${ }^{28}$

The immediate problem with the McGlinn rule is the lack of nineteenthcentury statutes authorizing courts to issue modern-day remedies such as TROs. Nevertheless, there are some antique statutes capable of providing such recourse. For example, in Cobb v. Cobb, Diane Cobb might have found recourse under an 1820 Massachusetts statute providing that, following the filing of a libel for divorce from the bonds of matrimony or from "bed and board,"29 a court is empowered to "prohibit the husband from imposing any restraint upon the personal liberty of the wife, during the pendency of such libel; and also to make such order or decree concerning the care and custody of the minor children of the parties." ${ }^{.30}$ The McGlinn rule fails as a solution to the enclave civil law problem, however, because it forces plaintiffs to unearth statutory fossils before they can attain recourse, and, as one commentator has noted, "[t]he cost of [this] legal research would make most suits impractical, leaving small or even fairly sizable claims unenforceable due to financial necessity."31 Such problems are compounded by the fact that most federal enclaves consist of tracts of land absorbed by the federal government at different times; the substantive law governing a single transaction involving several enclave tracts-for example, a suit for breach of contract where the cause of action has no tract-

24. Chicago, Rock Island \& Pacific Ry. v. McGlinn, 114 U.S. 542 (1885) (state liability law applies to railroad for incident occurring on military enclave). For a modern-day application of the McGlinn Rule, see City of Alameda v. Todd Shipyards Corp., 635 F. Supp. 1447, 1449-50 (N.D. Cal. 1986).

25. Paul v. United States, 371 U.S. 245,269 (1963) (federal policy precludes state milk pricing scheme from operating on California bases).

26. Howard v. Commissioners of The Sinking Fund of the City of Louisville, 344 U.S. 624 (1953) (Louisville's annexation of adjoining naval plant under exclusive legislative jurisdiction did not interfere in material way with enclave).

27. McGlinn, 114 U.S. at 546.

28. See Arlington Hotel Co. v. Fant, 278 U.S. 439 (1929) (private proprietor of hotel located in Hot Springs National Park held liable under common law for damages done to belongings of guest resulting from fire, despite state law passed nine years after cession releasing innkeepers from common law absolute liability); see also James Stewart \& Co. v. Sadrakula, 309 U.S. 94, 100 (1940).

29. This was considered a legal separation, terminable at the will of the parties. J. SCHOULER, A TREATISE ON THE LAW OF THE DOMESTIC RELATIONS § 222, at 343 (5th ed. 1895).

30. Army Brief, supra note 3 , at 8 (quoting 1820 MASs. ACTS, ch. 56, $\$ 1$; current statute codified at MASS. GEN LAWS ANN. ch. 208, § 18 (West 1986)).

31. Note, supra note 14 , at 758 . 
specific situs-might vary from tract to tract, all within the same federal enclave. $^{32}$

The Paul rule, the second of the three doctrinal approaches to enclave litigation, moves only slightly beyond the McGlinn rule by adding that a subsequent state regulatory scheme consistent with the "basic state law" in existence at the time of the transfer is also applicable within the enclave..$^{33}$ In sum, under the McGlinn rule, state laws can only be applied within enclaves if they were in effect when cession took place, while under the Paul rule, state laws generated subsequent to cession can be applied, provided they reflect the same basic scheme of domestic relations in effect when cession took place. For example, in Cobb v. Cobb, ${ }^{34}$ Massachusetts' current abuse prevention statute ${ }^{35}$ could have been applied on the grounds that it provides relief of a nature similar to that provided by the 1820 statute. ${ }^{36}$ The Paul rule does little to lessen the discretion of courts and the research burden placed on plaintiffs who are victims of domestic violence and in need of immediate recourse, however.

The third doctrinal approach, the most recent and presently the most applied, ${ }^{37}$ rejects the traditional enclave jurisprudence discussed above. As articulated in Howard v. Commissioners of Louisville $e^{38}$ and reiterated in Evans $v$. Cornman, ${ }^{39}$ the rule of noninterference dictates that all state laws are valid within federal enclaves unless they interfere with the jurisdiction asserted by the federal government. Issues involving federal-state relations are resolved through the premise that enclaves remain part of the surrounding state: "The fiction of a state within a state can have no validity to prevent the state from exercising its power over the federal area within its boundaries, so long as there is no interference with the jurisdiction asserted by the Federal Government."40 The practical result of the Howard rule in a domestic violence case with a

32. Altieri, supra note 11 , at 88 .

33. Paul v. United States, 371 U.S. 245,269 (1963).

34. 406 Mass. 21, 545 N.E.2d 1161 (1989).

35. See MASs. GEN. LAWS ANN. ch. 208, § 18 (West 1986):

The probate court in which the action for divorce is pending may, upon petition of the wife, prohibit the husband, or upon petition of the husband, prohibit the wife from imposing any restraint upon her or his personal liberty during the pendency of the action for divorce. Upon the petition of the husband or wife or of the guardian of either, the court may make such further order as it deems necessary to protect either party or their children, to preserve the peace or to carry out the purposes of this section relative to restraint on personal liberty.

See also MASS. GEN. LAWS ANN. ch. 208, § 19 (West 1986) (providing for temporary custody of minor children during pendency of divorce proceedings).

36. See supra notes $29-30$ and accompanying text.

37. Altieri, supra note 11 , at 90 . This trend towards applying the noninterference doctrine was recognized by the Cobb court. See supra note 12 and accompanying text.

38. 344 U.S. 624 (1953).

39. 398 U.S. 419, 424-25 (1970) (in light of fact that enclave residents are subjected to state criminal law, state taxes, state unemployment and workmen's compensation laws, vehicle registration and licensing laws, process and jurisdiction of state courts, and can use state courts and state public schools, enclave residents are "treated by the State of Maryland as state residents to such an extent that it is a violation of the Fourteenth Amendment for the State to deny them the right to vote").

40. Howard, 344 U.S. at 627. 
civilian-abuser is that, where a state court feels jurisdictionally certain enough to issue a temporary restraining order, ${ }^{41}$ the abuser will likely be ordered off base. However, in the case of a soldier-abuser, ${ }^{42}$ it is possible that the noninterference rule will protect the abuser from such an order on the grounds that it is in the federal interest that the soldier live on base-to be on call and immediately available to serve his commander. Without the commander's support, a state court order has no force. ${ }^{43}$

Predictability is lacking from all three traditional enclave doctrines: the McGlinn rule leaves legal research obstacles to be tripped upon by the unwary enclave resident who leaves the military installation in search of recourse; the Paul rule offers modern-day recourse only if it can be traced to the scheme of governing in effect during what may be the previous century; and the Howard rule offers state courts only tentative grounds for asserting jurisdiction, resulting in recourse for domestic violence victims that can be snatched away if a military commander chooses to call "interference." In light of the fact that all of these doctrines are in essence "good law," outcomes in enclave domestic violence litigation are covered with scales of unpredictability.

\section{Court Access for Enclave-Connected Civil Cases}

The doors of federal courts are closed to victims of domestic violence. ${ }^{44}$ The remaining options for obtaining recourse through the doctrines discussed

41. Because the abuser in this scenario is a civilian over whom, relative to military personnel, the military has little authority, military authorities are likely to seek a state court order before forcing the civilian-abuser out of his home and off base. See infra note 62 and accompanying text.

42. In this scenario, the abuser is a soldier in whom the military has an interest and may therefore protect from state authorities.

43. Brief of the Massachusetts Department of Social Services and the Attorney General as Amicus Curiae in Support of Plaintiff-Appellee at 29, Cobb v. Cobb, 406 Mass. 21, 545 N.E.2d 1161 (1989) (No. SJC-5039) [hereinafter Social Services Brief]. It should be noted that Army regulations arising out of the Secretary of the Army's general rulemaking authority may preempt state law even without express Congressional authorization to displace state law. See generally Free v. Bland, 369 U.S. 663 (1962) (Treasury regulation trumps state law). When preempting state law, military authorities do not have to overcome any presumption against federal administrative preemption of state law, nor do they have to sustain any strict scrutiny standard of review. See generally Fidelity Fed. Sav. \& Loan Ass'n v. Dela Cuesta, 458 U.S. 141, 152-54 (1982) (no express congressional authorization needed to displace state law). See also Standard Oil Co. of Cal. v. Johnson, 316 U.S. 481, 484 (1942) (holding that departmental regulations have force of law).

44. This forum is eliminated by the fact that federal courts deny jurisdiction in a variety of domestic relations matters even when diversity and amount in controversy are established. The rationale for federal court refusal to assert jurisdiction, discussed supra note 4, includes recognition of: (i) a strong state interest in domestic relations; (ii) the competence of state courts in settling family disputes; (iii) the possibility of incompatible federal and state court decrees in cases where there is continuing state court supervision; and (iv) congested federal dockets. Crouch v. Crouch, 566 F.2d 486, 487 (5th Cir. 1978). See generally Phillips, Nizer, Benjamin, Krim \& Ballon v. Rosenstiel, 490 F.2d 509 (2d Cir. 1973) (holding that federal diversity jurisdiction does not extend to matrimonial actions); Ostrom v. Ostrom, 231 F.2d 193 (9th Cir. 1955) (holding that federal district court has no power in divorce suits); P. BATOR, P. MISHKIN, D. SHAPIRO \& H. WECHSLER, HART \& WECHSLER'S THE FEDERAL COURTS AND THE FEDERAL SYSTEM 1189-1192 (2d ed. 1973). 
above are therefore the court within the state where the enclave sits and the court of some other state. Victims of domestic violence often face immediate danger, and therefore should be able to obtain recourse at the nearest court.

Most state law categorizes claims as either local or transitory, ${ }^{45}$ the latter capable of being brought anywhere personal jurisdiction over the parties can be obtained. ${ }^{46}$ In light of the fact that state courts are most familiar with adjudicating family law cases and federal courts refuse to adjudicate them, ${ }^{47}$ a victim of enclave domestic violence might find recourse in the local state court, or court of another state willing to embrace the claim as transitory, so long as service of the opposing party can be completed. ${ }^{48}$

Establishing a local claim often means meeting domiciliary requirements. Enclave residents capable of meeting residency requirements for the state in which the enclave is situated may claim the surrounding state as domicile and bring local actions. Nevertheless, many enclave residents will fail to meet jurisdictional requirements predicated on domicile: most are temporary residents on federal property and maintain permanent residency elsewhere. ${ }^{49}$ It should be noted, however, that there are some cases holding that enclave residency satisfies state jurisdiction requirements, ${ }^{50}$ and, for actions involving divorce, a number of states have enacted statutes providing that residency on military installations creates a presumption of state residency. ${ }^{51}$

45. Transitory claims typically are of either a tort or contract nature.

46. See Tennessee Coal, Iron \& R.R. Co. v. George, 233 U.S. 354, 355 (1914) ("A State cannot create a transitory cause of action and at the same time destroy the right to sue [on that transitory cause of action] in any court having jurisdiction....").

47. See supra note 44.

48. As established throughout this Note, when state courts arm enclave residents with protection from domestic violence, federal officials can take away that protection by claiming it interferes with the federal interest in establishing the enclave. The solution proposed in this Note, infra text accompanying notes 73105 , would change the preceding scenario so that, rather than taking away protection given by state courts through the doctrine of noninterference, federal officials would have to enter the appellate process to challenge state court decisions. The proposal also eliminates the hesitation of state courts to get involved by granting them jurisdictional certainty. Thus, at the very least, the proposed solution would offer the victims of domestic violence immediate recourse and time to contact family and friends, find alternative living arrangements, and file for divorce (thereby severing joint tenancies) before that recourse is taken away.

49. See, e.g., Lowe v. Lowe, 150 Md. 592, 133 A. 729 (1926) (holding residents of exclusive jurisdiction area, otherwise fulfilling state residency requirements, cannot file for divorce because not residents of state); see also Chaney v. Chaney, 53 N.M. 66, 201 P.2d 782 (1949) (holding residency in condemned area of Los Alamos Project does not satisfy residency requirements of divorce statute).

50. See, e.g., Shea v. Gehan, 70 Ga. App. 229, 28 S.E.2d 181 (1943) (in petition brought to have Veterans' Hospital patient adjudged insane, state courts have jurisdiction over any insane person found within their limits); In re Kernan, 247 A.D. 664, 288 N.Y.S. 329, aff d, Ex parte Kernan, 272 N.Y. 560 , 4 N.E.2d 737 (1936) (state court found to have jurisdiction to entertain divorced mother's habeas corpus proceeding to inquire into custody of child living at barracks with army officer father).

51. E.g., VA. CODE $\$ 20-97$ (1990 Ann.) (presumption of state residency for purposes of divorce actions for service members and their spouses living together for at least six months); TENN. CODE ANN. § 36-4104(b) (1984 repl. vol.) (presumption of state residency for purposes of divorce actions for service members or their spouses when residents for at least one year). 
Once a forum is chosen, that forum faces the problem of how to determine the applicable substantive law. With enclave-based domestic violence-such as in the case of $C o b b v$. Cobb-conflicts of law rules are likely to result in application of "enclave law," leaving courts to choose among the three doctrinal approaches discussed above. ${ }^{52}$

\section{Explaining the Lack of Litigation Over Enclave Domestic Violence}

According to military statistics, "[ $t]$ here were 11,931 substantiated reports of spouse abuse and 5,488 substantiated reports of child abuse (of both a sexual and nonsexual nature) involving both male and female soldier-perpetrators during the [two-year] period July 1, 1985 through June 30, 1987."s3 Beyond the fact that these figures do not account for soldier-victims such as Diane Cobb, they are conservative, ${ }^{54}$ if not misleading..$^{55}$

52. One problem not fully addressed by the proposed solution, and beyond the scope of this Note, is service of process. Although during this century many states have reserved authority to serve judicial process as a condition of cession, in the case of older enclaves, the ability of states to serve process upon residents of federal enclaves is a pressing procedural issue. See Altieri, supra note 11, at 71 . Under the present enclave doctrine, service can be disallowed where the process relates to an incident occurring within the installation, even if there has been a reservation of rights to serve process, on the grounds that such a reservation would enlarge the subject matter jurisdiction of the state to apply its substantive law, and, in doing so, would enable the state to interfere with the federal interest in establishing the enclave. See Weintraub, City of Philadelphia v. John E. Bullion-The Federal Enclave is Not a Sanctuary, ARMY LAW., Jan. 1980, at 16 n.4 (commander requiring legal office to review documents prior to service).

53. Arquilla, Crime in the Home, ARMY LAW., Apr. 1988, at 6 n.30.

54. As a point of comparison to the reported incidence rate of 17,419 over a two-year period for the 3,393,882 military personnel, DEPARTMENT OF DEFENSE, LIST OF MILITARY INSTALLATIONS, AUTHORIZED FUlL-TMIE ASSIGNED PERSONNEL (INCLUDING FY 1987), and their families (this figure is unavailable), consider the recorded incidents of domestic violence in Massachusetts-a state with a population of approximately 5,871,000. U.S. DEPARTMENT OF COMMERCE, STATISTICAL ABSTRACT OF THE UNTIED STATES XV (109th ed. 1989). The number of petitions filed for protection from abuse just by Massachusetts residents in Massachusetts, in 1988 alone, was 30,285. Social Services Brief, supra note 43, at 6 n.1 (citing Statistical Report of the Massachusetts Trial Court, 1985 and 1988).

Also, for a discussion of the pressures on the residents of military installations who are victims of domestic violence not to report their attackers, see Nichols, The Military Installation: How the Company Town Deals with Rape, Spouse Abuse and Child Abuse, 7 VICTMOLOGY 242, 250 (1982) ("Even if the care is sensitive [which, Nichols argues, it usually is not], a victim may choose not to report the attack because of the "company town' mentality which conditions her not to make waves.").

55. During the period October 1, 1986 through September 30,1987, the Army reported a rate of child abuse roughly one-third that of the national rate (the rate of child abuse in the Army during this period was reported as 10.2 children per 1,000 , while the national rate for 1985 was reported as 30.6 children per 1,000), Arquilla, supra note 53, at $4 \mathrm{n} .8$, in spite of the fact that $73 \%$ of Army soldiers are under thirty-one years of age, many married with children, UNITED STATES DEPARTMENT OF DEFENSE, DEFENSE '87 ALMANAC 30, 33 (Sept.-Oct. 1987), and that within the general population the rate of spouse and child abuse for husbands and wives under thirty-one years of age is more than twice that for husbands and wives between the ages of thirty-one and fifty, M. STRAUS, R. GELLES, \& S. STELNMETZ, BEHIND CLOSED DOORS-VIOLENCE IN THE AMERICAN FAMILY 129, 140-44, and 181-90 (1981). In fact, "Family Advocacy staff generally classify young families to be a 'high risk' population insofar as the likelihood of spouse and child abuse is concerned," Arquilla, supra note 53, at $4 \mathrm{n.8}$, which suggests that the Army's reporting rate for its young population should be at least as high as that of the general population. It has also been asserted that "[a] woman who admits to the [military] hospital that her injuries are a result of a beating from her husband may find that the entry in her medical records indicates that she fell down the stairs." Nichols, supra note 54, at 244. 
Though domestic violence on federal enclaves is substantial, there may be no recourse for its victims, since "those state civil laws requiring enforcement by state officials (e.g., child protection laws) only apply to the extent that federal laws and military regulations do not conflict with state law ... and the installation commander invites the state authorities, by agreement or otherwise, to exercise their authority on the installation." ${ }^{56}$ Agreements signed by installation commanders that immediately deliver domestic relations disputes into the hands of state courts and authorities are far from being the norm, since the military generally likes to take care of enclave-based domestic violence itself. Military procedure dictates that "the commander of the accused soldier ... decid[es] on whether a particular report of an abuse-related crime is supported by the available evidence, and, if so, whether the offense warrants prosecution or another disposition."57 It follows that "[t]he total number of abuse-related crimes being tried by court-martial is very small in relation to the total number of all substantiated reports of spouse and child abuse in the Army each year." ${ }^{28}$ Moreover, even if a state district court is not precluded from issuing restraining orders, and, once issued, such orders are legally effective within the confines of a federal enclave, state court orders do not necessarily pack an on-enclave impact: the power to carry out such orders on federal enclaves rests with military authorities. ${ }^{59}$

When domestic violence is caused by a soldier-abuser, ${ }^{60}$ the abuser is ultimately subject only to his commander's authority, which may mean protection from his victim's legal recourse. ${ }^{61}$ When a soldier, such as Diane Cobb, is the

56. Social Services Brief, supra note 43 app. C (Army Regulation 608-18). This is true to a lesser extent where, rather than the exclusive federal legislative jurisdiction common to most installations in the United States, there is concurrent legislative jurisdiction established through a state's reservation of rights. In the event of concurrent legislative jurisdiction, state civil and criminal laws apply and may be enforced by state officials in state courts, but, again, only to the extent that there is no interference with the federal function or military mission of the enclave.

57. Arquilla, supra note 53, at 4 (citing Army Regulation 608-18).

58. Id. at 12. ("IS]oldiers generally are not being tried by court-martial for abuse-related crimes, except in cases where they have killed their wives or children, or have raped or otherwise indecently assaulted their children.").

59. See supra note 43 and accompanying text. It also should be noted that, under the traditional view of exclusive legislative jurisdiction, local officials-such as local police officers-acting on enclaves under exclusive legislative jurisdiction lack authority and, consequently, may find that they are not entitled to immunity when sued. See Barr v. Matteo, 360 U.S. 564, 575 (1959) ('The fact that the action here taken was within the outer perimeter of petitioner's [a government agency director's] line of duty is enough to render the privilege applicable ....") (emphasis added).

60. Situations may also arise in which both the abuser and victim of abuse are soldiers:

One military wife told me that after she complained to her husband's commander about his beating her, the commander lectured his troops on the importance of not letting stress affect their job performance. He suggested that one way to let off steam was to 'beat your old lady.' The reason this military wife knew of the lecture is that she herself was on active duty at the time and was one of the troops lectured.

Nichols, supra note 54, at 244.

61. "The military community ... has a highly structured pecking order and it's likely that a person of high status would be more protected than he would in the civilian world." Id. at 245 . It should also be noted that, "[i]n a series of decisions beginning with United States v. Weeks, 20 M.J. 22 (C.M.A. 1985), 
victim of a civilian-abuser, the commander does not possess the same power to require the abuser to vacate the installation and may need the leverage of a court order to exercise authority. ${ }^{62}$ When the victim is a child and removal from her parents is necessary, army authorities are powerless without state law: there is absolutely no provision in military or federal law for the authorization of such removal. ${ }^{63}$

In sum, without guaranteed access to state law, there is no reliable protection for the victims of domestic violence who reside on federal enclaves-whether the victim is a soldier or civilian, adult or child ${ }^{64}$ The case of $C o b b$ v. Cobb, a recent illustration of this problem, provides a point of departure for the reexamination and reform of enclave doctrine.

\section{III. $C O B B$ V. COBB}

\section{A. The Factual Background ${ }^{65}$}

Diane Cobb, a service member in the United States Army, resides in Fort Devens, Massachusetts-a federal enclave. She has been married to James Cobb, a civilian, for three years, and they have a two-year-old son. On December 2, 1988, Diane filed a complaint in a Massachusetts state court seeking an order to restrain her husband from approaching, contacting or abusing her.

According to two affidavits filed in the lower court and Diane's testimony, James Cobb is an alcoholic and a drug abuser. In July 1988, James attacked Diane and threatened her with a knife; she subsequently fled to a women's shelter. Diane obtained an order from a Massachusetts state district court restraining her husband from abusing her and ordering him out of their home.

the Court of Military Appeals held that evidence of good military character is admissible as substantive evidence to prove that an accused did not commit the charged acts . . . . An outstanding combat record has traditionally been a mitigating factor in adjudging a sentence and in reviewing its appropriateness." United States v. Benedict, 20 M.J. 939, 944 (1985) (citations omitted) (in case of general court-martial conviction for indecent acts with ten-year-old girl, court considered accused's superior record for service and determined appropriate only so much of sentence as provided for dismissal, confinement at hard labor for eighteen months, and forfeiture of pay and allowances).

62. "The jurisdiction of military tribunals does not extend to persons, including military dependents who reside on federal enclaves, who are not members of the armed forces . . . " In re Terry Y., $101 \mathrm{Cal}$. App. 3d 178, 182, 161 Cal. Rptr. 452, 454 (1980) (citation omitted); see also supra note 13.

63. Social Services Brief, supra note 43 , at 23-24.

64. The current lack of adequate protection for child victims of military abusers on federal enclaves was recognized in the child abuse/custody case of Terry Y.: "Unless Monterey County acts to protect the children at Fort Ord, these children may be left without governmental protection." Terry Y., 101 Cal. App. 3d at 182, $161 \mathrm{Cal}$. Rptr. at 454. And, as one military scholar has noted, "[m]eeting the needs of these children requires not only an Army family action plan, but action by society as well." Arquilla, supra note 53, at 13 (footnote omitted). Although it has been held that state laws regarding both mental commitment and the guardianship of neglected children apply to persons living on military bases, Board of Chosen Freeholders v. McCorkle, 98 N.J. Super 451, 237 A.2d 640 (1968), the application of these laws is conditioned upon there being no interference with the jurisdiction asserted by the federal government.

65. See Plaintiff Brief, supra note 2, at 4-7 (factual situation as it existed when the case was heard by the Supreme Judicial Court of Massachusetts on September 5, 1989). 
James then began attending Alcoholics Anonymous meetings and sought help from a psychiatrist, and the couple began to see a marriage counselor. In August 1988, Diane permitted her husband to move back home, and in October she requested that the restraining order be lifted.

But soon the alcohol abuse resumed, and so did the violence and physical abuse. Diane asked for a divorce. James initially agreed to leave their house. However, upon returning home from work on several occasions, Diane discovered him hiding in closets. On one occasion, Diane discovered him hiding in the attic; at that time James told Diane that he planned to kill her.

Ultimately, James Cobb was charged with armed assault and assault with intent to kill. Knowing that Diane was to return from a Thanksgiving holiday, James armed himself with a knife, waited at the airport, and, when he saw soldier Eric Jackson who was there to pick Diane up, he stabbed Jackson with a knife.

Diane, fearful for her life and the life of her two-year-old child in the event of her husband's release from jail, sought protection from a Massachusetts state court. This plea for protection raised the question of whether a state court is deprived of jurisdiction to restrain potential acts of domestic violence because the victim of abuse is a member of the United States Armed Forces and resides on a federal enclave. ${ }^{66}$

\section{B. Rethinking the Doctrine in Light of Cobb v. Cobb}

$C o b b$ v. Cobb put the Department of the Army in the awkward position of arguing in favor of using a state court to protect one of its own, while attempting to shield the doctrine of exclusive legislative jurisdiction for federal enclaves from the noninterference approach. ${ }^{67}$ This is an interesting twist on cases in which federal supremacy insulates military personnel and employees from state remedies that would, allegedly, interfere with the performance of assigned duties-a TRO to keep an abusive soldier away from his wife who is residing on a military base, for example. Hence, Cobb v. Cobb illustrates that, in domestic violence cases, the application of state law on federal enclaves is necessary to protect soldiers as well as civilians. ${ }^{68}$

According to the Department of the Army, even the doctrine of noninterference (a presumption in favor of applying state law in federal enclaves) is unac-

66. See supra note 12.

67. See Army Brief, supra note 3. As mentioned previously, the Army argued in favor of applying the McGlinn rule and granting recourse under an 1820 Massachusetts statute. See supra notes 29-32 and accompanying text.

68. Permitting enclave domestic violence to be treated by state courts applying state law is also in the general public's interest: "The military community is not a separate, isolated nation. Its residents are merely human beings who follow a certain life style for a number of years. They interact with members of the civilian community, for better or worse, and eventually become civilians themselves." Nichols, supra note 54 , at 251. 
ceptable since it "would destroy all significance to federal enclaves because even on non-federal enclaves, federal law supersedes any interfering state law by virtue of the supremacy clause." ${ }^{169}$ In light of such military resistance to anything less than pure ${ }_{c}$ veto power over the application of state law, unless domestic violence is held above government claims of interference, the supremacy clause, ${ }^{70}$ exclusive legislation clause, ${ }^{71}$ and property clause ${ }^{72}$ ensure that the federal government always will be able to challenge the application of state law within federal enclaves on the grounds that it interferes with federal interests. In the absence of a domestic violence exception to the noninterference doctrine, relief for soldier-victims may be delayed due to the jurisdictional uncertainty of state courts; and when the Diane Cobbs are not soldiers but are married or born to them, they may find no redress for their suffering.

\section{TERRY Y.: The BeginNINGS OF A SOLUTION}

Congress has responded to the enclave jurisdiction problem in the area of criminal law through the Assimilative Crimes Act. ${ }^{73}$ But, in the area of civil law, Congress' response has been more piecemeal: state unemployment laws, ${ }^{74}$ workmen's compensation laws, ${ }^{75}$ state laws governing actions for personal injury and wrongful death, ${ }^{76}$ and state taxing laws under the Buck Act ${ }^{77}$ are the pieces of civil law that have been assimilated into federal enclave law. Congress has not yet responded to the problem of domestic violence on federal enclaves.

A domestic violence exception must be carved out of the exclusive legislative jurisdiction of federal enclaves. Congress should either enact legislation or expand the Assimilative Crimes Act to include federal recognition of temporary restraining orders issued by state courts ${ }^{78}$ in cases of enclave domestic

69. Army Brief, supra note 3 , at 13 .

70. U.S. CONST. art. VI, cl. 2. For text of clause, see supra note 7.

71. U.S. CoNST. art. I, $\S 8, \mathrm{cl}$. 17. For text of clause, see supra note 6 .

72. U.S. CoNST. art. IV, $\S 3, \mathrm{cl}$. 2. For text of clause, see supra note 8 .

73. 18 U.S.C. $\$ 13$ (1987) (incorporates certain state criminal laws into federal law applicable on federal enclaves, essentially making state criminal law federal law). The Assimilative Crimes Act was intended to patch over holes in the criminal law applicable to federal enclaves by incorporating state law. Therefore, state criminal statutes are not assimilated when there is applicable federal law (no hole to patch over). See United States v. Kaufman, 862 F.2d 236, 237 (9th Cir. 1988).

74. 26 U.S.C. § 3305(d) (1988).

75. 40 U.S.C. $\$ 290$ (1982).

76. 16 U.S.C. $\S 457$ (1988).

77. 4 U.S.C. $\$ 104-10$, as discussed in Weintraub, supra note 52 , at 15 .

78. The Assimilative Crimes Act turns state criminal law into federal law to be applied by federal courts. As established above, supra note 44 and accompanying text, federal courts are not family courts, nor are they likely to have any interest in acting as family court surrogates. Moreover, civilian victims should not be limited to seeking recourse from courts within the military community-a community that relies on its service members to carry out the military mission that is its sole purpose for existence, and whose legal system applies justice with an eye on one's service record. See supra note 61 . 
violence. ${ }^{79}$ A state court and state-law-specific provision is essential, for, without such a provision, the restraining order recourse provided by an expanded Assimilative Crimes Act might melt in the hands of military discretion: "State laws are not applied to federal enclaves through the Assimilative Crimes Act if the state law provision would conflict with existent federal law or policy." ${ }^{80}$ To keep their problems at home, military courts could, in the name of military and thus federal interest, shield the assimilation of such state law remedies by holding up inadequate enclave-generated remedies. ${ }^{81}$

Federal policy preemption ${ }^{82}$ must be avoided for cases of domestic violence. Thus, to the Assimilative Crimes Act must be fused recognition that there is a federal interest in providing the victims of domestic violence with the highest possible level of recourse. Courts have begun to nudge the law in this direction by adopting the doctrine of noninterference's presumption in favor of applying state law: all state laws are valid within federal enclaves unless they interfere with the jurisdiction asserted by the federal government. ${ }^{83}$ However, while the victims of enclave domestic violence are awaiting a response from Congress, courts should go further and limit the circumstances in which the federal government may yell "interference" by explicitly recognizing that the protection of victims of domestic violence is itself a federal interest with which other government interests should not interfere. Precedent for this, to some extent, has been set at the state level in the case of In re Terry $Y{ }^{84}$

79. A similar provision was added to the Assimilative Crimes Act for driving under the influence of drugs or alcohol, and there have been a number of criminal prosecutions of soldiers for drunk driving. See, e.g., United States v. Hamilton, 838 F.2d 1210 (4th Cir. 1988); United States v. Mariea, 795 F.2d 1094 (1st Cir. 1986). In light of these successful drunk-driving convictions, it should be noted that crimes of domestic violence, although categorized as "civil" in nature, are violent crimes and therefore deserve the same response Congress has extended to criminal actions.

80. King v. Gemini Food Serv., Inc., 438 F. Supp. 964, 966 (E.D. Va 1976), aff'd, 562 F.2d 297 (4th Cir. 1977), cert. denied, 434 U.S. 1065 (1978).

81. See United States v. Fulkerson, 631 F. Supp. 319 (D. Haw. 1986) (federal agency regulations enacted pursuant to congressional authority have force of law and may preempt assimilation of state law through Assimilative Crimes Act); see also United States v. Eades, 615 F.2d 617 (4th Cir. 1980) (Congress preempted Maryland crime of third-degree sexual offense by making simple assault and aggravated forms of assault federal offenses); United States v. Butler, 541 F.2d 730 (4th Cir. 1976) (fact that federal statute is narrower in scope than that offered by state law prohibiting similar conduct does not allow federal government to use state law to broaden definition of federal crime).

82. Such preemption could take a number of forms (e.g., reference to Military Family Action Plans). As established throughout this Note-see supra notes 53-55 and accompanying text-there is reason to believe that recourse from within the military community is not enough. See also infra note 96 and accompanying text. The seriousness of the problem suggests that error should be made on the side of providing too much recourse. Victims should have access to both on-base and off-base recourse; the choice should be theirs.

83. See infra note 105 and accompanying text regarding enforcement of state court orders.

84. 101 Cal. App. 3d 178, 161 Cal. Rptr. 452 (1980). 


\section{A. The Significance of In re Terry Y.}

Terry $Y$. involved the removal of an abused child-after he suffered four fractures over a two-year period-from his parents who lived on a military base. ${ }^{85}$ Noting that, "in the area of the rights of federal enclave residents to state benefits, there has been a trend in state courts to hold that the exclusive jurisdiction of Congress does not deprive enclave residents of benefits which would otherwise be theirs," the court exercised the noninterference presumption in favor of applying state law. ${ }^{86}$ Moreover, it sustained that presumption against protests that the juvenile court's exercise of jurisdiction conflicted with federal sovereignty by recognizing that " $[t]$ he Monterey County Juvenile Court's exercise of its statutory jurisdiction to protect Terry promoted the federal policy toward abused children as reflected in the applicable Army Regulations and the Social Security Act." ${ }^{\text {87 }}$

The Terry Y. decision is significant because a congressional policy, articulated in a federal statute, was used to shield the domestic relations remedy granted by a local court from claims of federal jurisdiction. ${ }^{88}$ Nevertheless, Terry $Y$. by itself is not enough to carry the doctrine of noninterference beyond helping soldier-victims. In Terry Y, as in Cobb v. Cobb, military personnel not only declined to oppose the jurisdiction of the state courts, they actively sought it. ${ }^{89}$ Moreover, the Terry $Y$. decision relied on congressional legislation to

85. Id.

86. Id. at 453, citing Note, Rights of Federal Enclave Residents to State Residency Benefits, 49 CALIF. L. REV. 550 (1961).

87. 161 Cal. Rptr. at 455. The court relied upon Board of Chosen Freeholders v. McCorkle, 98 N.J. Super. 451, 237 A.2d 640 (1968), from which it quoted: "The conferring of a benefit required by federal law cannot be construed as an act which undermines the federal sovereignty." 161 Cal. Rptr. at 454 .

The Supreme Court of Colorado applied this same reasoning earlier in County Commissioners of Arapahoe v. Donoho:

The conferring of a benefit required by federal law cannot be construed as an act which undermines the federal sovereignty. Indeed by paying relief in these circumstances the federal policy to recognize citizens of the United States is fostered and promoted. . . . It is illogical to suppose that the federal government would interfere with the county carrying out a program contemplated by federal statute.

144 Colo. 321, 332-33, 356 P.2d 267, 273-74 (1960) (case in which county welfare board denied claim of resident of military installation under exclusive legislative jurisdiction).

88. Specifically, the Terry Y. court relied upon Title IV-B of the Social Security Act, 42 U.S.C. $\S \S$ 620-26, which authorizes grants to the states for establishing, extending and strengthening child welfare services. $101 \mathrm{Cal}$. App. 3d 181, 183, $161 \mathrm{Cal}$. Rptr. 452, 454. The court's rationale was that:

In order to qualify for funds allotted under Title IV-B, a state must make a satisfactory showing that it is making available its child welfare services 'in all political subdivisions of the State, for all children in need thereof'(42 U.S.C. § 622(a)(2)). As federal enclaves such as Fort Ord remain geographically and legally a part of the state in which they are located, it follows that Congress contemplated that the state would make its services available to the children on federal enclaves.

101 Cal. App. 3d 181, 183, 161 Cal. Rptr. 452, at 455 (1980) (citation omitted).

89. 101 Cal. App. 3d at 182, $161 \mathrm{Cal}$. Rptr. at 454; see also Army Brief, infra note 95. 
shore up its "federal policy" argument. ${ }^{90}$ Thus, the federal interest in protecting Terry $Y$. was insulated from exclusive legislation clause ${ }^{91}$ challenges.

Federal policy arguments are more difficult to come by in the area of spouse abuse. However, although explicit congressional legislation is lacking, ${ }^{92}$ federal interest in providing recourse has been codified to a limited degree in the Victims of Crime Act of $1984 .{ }^{93}$ In fact, state programs that do not extend onto federal enclaves may be denied federal funding: The eligibility requirements for state victim compensation programs seeking the federal funds established by this Act explicitly state that such programs must provide "compensation to victims of crimes occurring within such State that would be compensable crimes, but for the fact that such crimes are subject to federal jurisdiction, on the same basis that such program provides compensation to victims of compensable crimes." 94

There are also Army regulations and procedures which might be cited as recognition of a federal policy to prevent and provide recourse for domestic violence..$^{95}$ For example, Army Family Action Plans are generated annually through conferences, attended by representatives from all major Army commands, in which "those who seek to advance the interests of Army families in spouse and child abuse cases, as well as in all other areas of military life, have

90. The federal interest in preventing child abuse has been shored up even further by the Children's Justice and Assistance Act of 1986, 42 U.S.C. $\$ \S 290 d d-3,290 \mathrm{ee}-3,5101,5103,5105,5117$ et. seq., 10601, 10603, 10603a (1982). The objectives of this Act include: (i) encouraging states to enact child protection reforms; (ii) protecting child victims from further abuse during proceedings and increasing the chances of successful legal action against abusers; (iii) requiring participating states to adopt recommendations of multidisciplinary task forces on child abuse; (iv) amending the Victim of Crime Act of 1984 to authorize child abuse prevention and treatment grants; (v) directing the National Center on Child Abuse and Neglect to disseminate information to states and local officials; and (vi) authorizing disclosure of alcohol and drug abuse patient treatment records to facilitate reporting of child abuse and neglect. See 42 U.S.C. § 5103 (1982).

91. U.S. CONST. art. I, $\S 8$, cl. 17. For text of clause, see supra note 6 .

92. This may soon change, for United States Senator Dan Coats recently articulated his intention to introduce legislation to increase awareness about and prevent domestic violence, and Senator Joseph Biden has already introduced the Violence Against Women Act of 1990, which attempts to make both the streets and homes safer for women and extends civil rights protection to victims of sex crimes. See Coats Looks at Family Abuse Laws, United Press International, August 29, 1990, Wednesday (BC cycle); Lopez, supra note 92 . Biden's bill provides $\$ 25$ million to establish special spouse-abuse prosecuting units and doubles funding for battered spouse shelters. See Phillips, Legislation Planned to Combat Violence Against Women, Gannett News Service, June 19, 1990, Tuesday.

93. Pub. L. No. 98-473, tit. II, ch. XIV, § 1404, 98 Stat. 2172 (1984), current version at 42 U.S.C.A. $\S 10603$ (West Supp. 1990) (stating that, as to federal grants for state crime victim assistance programs, "priority shall be given to eligible crime victim assistance programs providing assistance to victims of sexual assault, spousal abuse, or child abuse").

94. 42 U.S.C.A. § 10602 (West Supp. 1990). The eligibility standards also stipulate that such programs must make "compensation awards to victims who are nonresidents of the State on the basis of the same criteria used to make awards to victims who are residents of such State." Id.

95. The Department of the Army has itself articulated this federal policy in its Cobb v. Cobb brief: "The availability of such relief to service members residing on a federal enclave is also a question of great concern to the Department of the Army because of its vital interest in protecting soldiers and their family members from domestic violence." Army Brief, supra note 3, at 1. 
a forum."96 It is difficult to argue credibly that a military claim of interference with a military mission is mooted by a federal policy simply because this policy is articulated in military regulations. It might be credibly argued, however, that a given military commander's discretionary claim of interference is mooted by an overarching federal policy of protecting the victims of domestic violence, as articulated in the military institution's regulations. Whether this would encourage the military to abandon such regulations, however, is a question that cannot be ignored.

\section{B. The Federal Interest in Protecting Victims of Domestic Violence}

To protect the victims of abuse from soldier-abusers with or without the support of military authority and ensure state court jurisdiction and recourse for soldier-victims, the Terry $Y$. holding must be expanded. The federal interest in protecting victims of domestic violence who live on federal enclaves should be recognized as a federal interest-a protected interest capable of enduring most military claims of interference. ${ }^{97}$

Since a woman is beaten about every eighteen seconds, ${ }^{98}$ one out of every thirteen murders in the United States involves the killing of a spouse, and in one out of every five murders the victim is a family member of, or involved romantically with, his or her killer, ${ }^{99}$ it is difficult to imagine how a restraining order on a soldier-abuser could interfere with, or be contrary to, the overall

96. Arquilla, supra note 53, at 4; see, e.g., Department of Army, Pamphlet No. 608-41, Personal Affairs-The Army Family Action PIan IV (June 19, 1987) (updated versions of pamphlet have been generated for 1988 to present); see also Army Regulation 608-18, Chapter 7, issued by order of the Secretary of the Army on September 18, 1987 (describing the Army Child Advocacy Program, ACAP).

As established previously, however, in light of (i) the discretionary power granted to enclave commanders, (ii) the fact that the military has a vested interest in its soldiers, and (iii) the "company town" pressure not to report such crimes articulated in Nichols, supra note 54, off-enclave state recourse must be available for the victims of enclave-based domestic violence.

97. This principle of filling in the enclave civil law gap to offer on-enclave protection equal to that available around enclaves was realized over a half a century ago in the area of workmen's compensation: "The purpose of the amended bill is to fill a conspicuous gap in the workmen's compensation field by furnishing protection against death or disability to laborers and mechanics employed by contractors or other persons on Federal property." S. REP. NO. 2294, 74th Cong., 2d Sess. 1 (1936); "The bill is absolutely necessary so that protection can be given to men employed on projects as set out in the foregoing paragraph." H.R. REP. No. 2656, 74th Cong., 2d Sess. 1 (1936).

98. Phillips, Legislation Planned to Combat Violence Against Women, Gannett News Service, June $19,1990$.

99. UNITED STATES DEPARTMENT OF JUSTICE, UNIFORM CRME REPORTS FOR THE UNTIED STATES at 12 (1988) (calculated by compiling statistics that (i) wives are victims of 5.2 percent and (ii) husbands are victims of 2.3 percent of all murders). In light of the preceding, consider that, according to the United States Department of Justice's national statistics for 1988, "[a]mong all female murder victims in 1988, [thirty-one] percent were slain by husbands or boyfriends," and "five percent of the male victims were killed by wives or girlfriends." Id.; see also Lopez, Landmark Bill Would Attack Escalating Violent Crime, Chicago Tribune, July 1, 1990, Sunday (final ed.) ("The crime rate against women in the United States is significantly higher than in other countries, with three out of four likely to be victims of at least one violent crime during their lifetimes ...."). 
federal interest. ${ }^{100}$ The military is not without capacity to work around such orders so as to continue carrying out the federal functions of its enclaves. ${ }^{101}$ Even if, in the extreme example, it is absolutely necessary for a soldier-abuser to reside on base, the military could accommodate the federal interest of preventing domestic violence by supplying alternative enclave housing for the abuser. The victims of domestic violence should not be pushed outside their homes.

Another, perhaps preferable, alternative would be for the military, with the victim's consent, to finance comparable off-enclave housing for the victim of abuse until the restraining order protecting her is removed or until the victim is able to finalize a divorce. ${ }^{102}$ This would not only separate the victim from her soldier-abuser, but would also enable her to separate herself from the closeknit military community. Moreover, at least where children are involved, this off-base housing might be partially financed by the abuser through a state support order. ${ }^{103}$ If the soldier violates a restraining or support order, he should be subjected to sanctions deemed appropriate by the state court ${ }^{104}$ that issued the order. ${ }^{105}$

100. For example, domestic violence cases would be distinguished from instances where a federal interest in completing a military mission trumps other interests, such as in Laine v. Weinberger, $541 \mathrm{~F}$. Supp. 599, 604 (1982) (concerned citizens seeking to enjoin nuclear weapons storage on naval weapons station denied relief on grounds that "a State is powerless to condition the means by which the Federal Government carries out its activities"). Moreover, the proposed approach, focused as it is on domestic violence, does not scrape against much of the extreme in enclave case law-case law firmly maintaining the concept of "a state within a state" and allowing federal policy to completely displace state law. See, e.g., United States v. Mississippi Tax Comm'n, 412 U.S. 363 (1973), on remand, 378 F. Supp. 558 (S.D. Miss. 1974), rev'd, 421 U.S. 599 (1975) (state tax and regulatory schemes attempting to reach liquor sales on federal enclaves defeated); see also Lord v. Local Union No. 2088, 646 F.2d 1057 (5th Cir. 1981), cert. denied, 458 U.S. 1106 (1982) (federal policy in favor of union security clauses in language of National Labor Relations Act, requiring all workers to be members of union, displaced state law); United States v. Texas, 695 F.2d 136 (5th Cir. 1983) (Navy defeating Texas' efforts to stop out-of-state liquor sellers from selling directly to Navy; Navy efforts to procure liquor at lowest price possible consistent with Department of Defense policy).

101. The United States has conceded that federal enclaves are not foreign entities but are elements of the state in which they are located-permitting state courts to apply state laws until that permission is withdrawn. See Offutt Housing Co. v. Sarpy County, 351 U.S. 253, 260-61 (1956) (allowing state taxation of military housing); see also Evans v. Cornman, 398 U.S. 419 (1972) (treating residents of federal enclave as state residents for purposes of Fourteenth Amendment protection). The position taken throughout this Note is that, in the area of domestic violence where federal courts and federal legislatures have declined to extend jurisdiction, permission given to state courts to apply state laws should not be withdrawn and the recourse it offers should be guaranteed.

102. A "Teasonable time" standard could be adopted to limit abuse of the alternative housing option.

103. "Federal law also authorizes involuntary allotments from military pay [42 U.S.C. $\S 665$ (1982)] and garnishment of military and retired pay [42 U.S.C. \& 659 (1982)] to enforce state child support and alimony orders." Arquilla, supra note 53, at 9.

104. Due to federal court refusal to assert jurisdiction for various reasons, state courts are the issuers of such orders for private disputes. See supra notes 4,44 .

105. Although carrying out abuse prevention orders is left to the discretion of commanders, state courts do retain the remedial powers of civil and criminal contempt. The residents of military bases, just as persons residing in other states or foreign countries, should be no more immune from judgments of contempt than civilians. In support of this proposition, see Kennedy v. Kennedy, 20 Mass. App. Ct. 559, 563, 481 N.E.2d 1172 (1985) (attachment of United States military pay and pension as remedy for contempt). Moreover, at least where there are restraining order statutes such as Massachusetts' MASS. GEN. LAWs ANN. ch. 209A, $\$ 7$ (West 1987), which provides that violations of abuse orders are criminally punishable, restraining order 


\section{CONCLUSION}

State law should be made accessible, and state courts should be granted jurisdiction, to enforce local domestic relations laws on federal enclaves in order to guarantee the safety of victims of domestic violence residing thereon. Whether or not these enclave-resident victims of domestic violence are offered any legal remedy must not remain at the discretion of the enclaves' military commanders and subject to the hesitation of state courts unsure of their jurisdiction.

In light of the constitutional mandate that federal government interests prevail within federal enclaves, the Assimilative Crimes Act should be amplified to codify federal recognition of state court restraining orders for cases of domestic violence. In the meantime, courts must continue to nudge development of the law in this direction by adopting a modified doctrine of noninterference which recognizes the federal interest in protecting all citizens from domestic violence.

While continuing to respect exclusive federal legislative jurisdiction and allowing the completion of military missions, this linkage would guarantee recourse for victims of domestic violence, whether soldier or civilian, where there may otherwise be none. As illustrated through the case of Diane Cobb, making protection immediately and unambiguously available to enclave victims of domestic violence promotes everyone's best interest.

violations could be prosecuted under the Federal Assimilative Crimes Act, 18 U.S.C. $\S 13$ (1988). 